\title{
Biomass and Sugar Content of Some Varieties of Sorghum (Sorghum Bicolor L. Moench) on Dry Land Forest as Feedstock Bioethanol
}

\author{
Praptiningsih Gamawati Adinurani ${ }^{1 *}$, Sri Rahayu ${ }^{1}$, Luluk Sulistiyo Budi ${ }^{1}$, Anggi Nindita $^{2}$, Peeyush Soni $^{3}$, and \\ Maizirwan $\mathrm{Mel}^{4}$ \\ ${ }^{1}$ Faculty of Agriculture, Merdeka University of Madiun, Jl. Serayu No.79, Pandean, Madiun, Jawa Timur 63133, Indonesia \\ ${ }^{2}$ Department of Agronomy and Horticulture, Faculty of Agriculture, Bogor Agriculture University, Jl. Meranti, Bogor, \\ 16680 , Indonesia \\ ${ }^{3}$ Departement of Food, Agriculture and Bioresources, School of Environment, Resources and Development, Asian Institute \\ of Technology, PO Box 4, Klong Luang Pathumthani 12120, Thailand. \\ ${ }^{4}$ Department of Biotechnology Engineering, International Islamic University Malaysia, Jalan Gombak, Kuala Lumpur \\ 53100, Selangor, Malaysia
}

\begin{abstract}
The possibility of sustainable use of sorghum as raw material for bioethanol needs to be supported by evaluation and selection of sorghum varieties for high biomass production and sugar content. An experiment was conducted on forest dry land, altitude $63 \mathrm{~m}$ asl. This research aimed to determine the interaction of sorghum varieties and mycorrhiza on biomass production and the high sugar content. The experiment was a two factor (varieties and dosage of mycorrhiza plus) in a randomized complete block design with three replications. The varieties were Suri 3, Kawali, Super 2, Suri 4. Dosage of mycorrhiza plus $(5,10,15) \mathrm{g}$ per plant. The interaction only significant on a number of internodes and bagasse. There are no effects of dosages mycorrhiza plus, however, varieties of sorghum have significant effects on many variables measured. The highest amount of biomass include the stem height $(301.28 \mathrm{~cm})$, stem Dry Weight (DW) is 23.48 $\mathrm{t} \mathrm{ha}^{-1}$, leaf DW $\left(4.65 \mathrm{t} \mathrm{ha}^{-1}\right)$, panicle DW $\left(11.35 \mathrm{t} \mathrm{ha}^{-1}\right)$ and biomass DW $\left(39.98 \mathrm{t} \mathrm{ha}^{-1}\right)$ were obtained in varieties Super 2. Sugar content (16.93\%) was obtained in varieties Suri 3 and juice production $\left(2742.86 \mathrm{~L} \mathrm{ha}^{-1}\right)$ in varieties Suri 4.
\end{abstract}

Keywords: Biomass, sorghum, sugar content, varieties.

\section{Introduction}

Since the Government of Indonesia has made it mandatory to blend bioethanol and fossil fuels increases the need for bioethanol. Sweet sorghum (Sorghum bicolor L. Moench) is a possible candidate for a renewable source of bioethanol. Sweet sorghum is a multiple-purpose crop which has been consumed as either food [1] or feed [2], and industrially cultivated for liquid sugar and ethanol production [3, 4]. Sweet sorghum has been identified as an energy commodity for high sugar content in stem $[5,6]$. Sugar content in the juice of sweet sorghum stalks ranging from (8 to 20) \% [7] and is capable of producing ethanol (6 000 to 7000$) \mathrm{L} \mathrm{ha}^{-1}[8,9]$. In Indonesia, the ability of sorghum to produce ethanol ranges between (3 000 to 6600$) \mathrm{L} \mathrm{ha}^{-1}$ [10]. The production costs of biofuel from sweet sorghum are cheaper than that from sugarcane in the USA [11]. Ethanol production is determined by the production of biomass and sugar content in stem [12, 10]. Among the parts of the sorghum, stems give contributed most to produce juice as bioethanol feedstock. The average productivity of sorghum stalks ranges (30 to 50) $\mathrm{tha}^{-1}$ and leaf (20 to 40) $\mathrm{tha}^{-1}$ [13].

Sorghum has great potential to be cultivated and developed commercially because it has wide adaptability, high productivity, relatively little input, resistant to pests and plant diseases, drought tolerant, salinity and sour landly $[14,15]$. Therefore, efforts to explore the potential of sweet sorghum as a feedstock for ethanol that cultivated on the forest land and popularization of sweet sorghum varieties.

\footnotetext{
${ }^{*}$ Corresponding author: praptiningsih.ga@gmail.com
} 
The Vesicular-Arbuscular Mycorrhizal (VAM) is a mutualistic symbiosis between fungi and the roots of plants. Also improved P nutrition by VAM fungi during the periods of water deficit has been postulated as a primary mechanism for enhancing host plant drought tolerance and assists host plants to use $\mathrm{N}$-forms [16] and potential to increase the growth and productivity of plants, especially on marginal lands. The purpose of this research is to know the productivity of biomass and sugar content of several varieties of sorghum cultivated in the forest land.

\section{Methods}

\subsection{Field location}

The experiment was conducted at the forest land area village Kampung Baru District of Saradan Madiun, with a height of $63 \mathrm{~m}$ asl (above sea level). Soil characteristics consist of $\mathrm{C}$-Organic $=1.59 \%$; N-total $=1.15 \% ; \mathrm{C} / \mathrm{N}$ ratio $=1.5 ; \mathrm{P}_{2} 0_{5}$ available $=86.75 \mathrm{mg} \mathrm{kg}^{-1} ; \mathrm{P}_{2} 0_{5}$ total $=269.64 \mathrm{mg} \mathrm{kg}^{-1}$ and $\mathrm{pH} 5.37$.

\subsection{Experimental design}

This experiment was arranged in the randomized complete block design (RCBD) with two factors in three replications. The first factor was varieties of sorghum, the varieties consist of Suri 3 (V1), Kawali (V2), Super 2 (V3) and Suri 4 (V4). The second factor was dosage of mycorrhiza plus in three levels, $5 \mathrm{~g}$ per plant (D1), 10g per plant (D2), and $15 \mathrm{~g}$ per plant (D3). The mycorrhiza plus contains mycorrhiza endogen i.e.Trichoderma sp., Pseudomonas fluorescent and Bacillus subtilis.

\subsection{Statistical analysis}

Analysis of variance (ANOVA) and means comparisons were computed by Statistical Packages for The Social Sciences (SPSS). Duncan range test was used to analyze significant differences between treatments and its combinations.

\section{Results and discussion}

Analysis of variance showed that combination treatments between sorghum varieties and Mychorrhizal dosage are tended to differ among treatments combination. This resulted in a number of internodes and bagasse fresh weight (Table 1).

Table 1. Sorghum varieties and Mychorrizal means interactions of internode number and bagasse fresh weight.

\begin{tabular}{|c|l|l|}
\hline $\begin{array}{c}\text { Treatment } \\
\text { Combination }\end{array}$ & Number of internodes & Bagasse Fresh Weight $\left(\mathrm{t} \mathrm{ha}^{-1}\right)$ \\
\hline V1D1 & $8.67 \mathrm{abc}$ & $90.9 \mathrm{abc}$ \\
\hline V1D2 & $8.00 \mathrm{ab}$ & $146.4 \mathrm{cde}$ \\
\hline V1D3 & $7.11 \mathrm{ab}$ & $150.63 \mathrm{cde}$ \\
\hline V2D1 & $10.78 \mathrm{bc}$ & $122.60 \mathrm{bc}$ \\
\hline V2D2 & $8.66 \mathrm{abc}$ & $81.27 \mathrm{ab}$ \\
\hline V2D3 & $8.0 \mathrm{ab}$ & $127.70 \mathrm{bcd}$ \\
\hline V3D1 & $11.44 . \mathrm{c}$ & $62.33 \mathrm{a}$ \\
\hline V3D2 & $11.77 \mathrm{c}$ & $188.60 \mathrm{ef}$ \\
\hline V3D3 & $10.67 \mathrm{bc}$ & $96.00 \mathrm{abc}$ \\
\hline V4D1 & $9.00 \mathrm{abc}$ & $182.00 \mathrm{def}$ \\
\hline V4D2 & $7.67 \mathrm{ab}$ & $104.07 \mathrm{abc}$ \\
\hline V4D3 & $9.44 \mathrm{abc}$ & $210.00 \mathrm{f}$ \\
\hline
\end{tabular}

Note: Mean followed by the same letter are not significantly different based on Duncan range test at 0.5 level.

High bagasse fresh weight of sorghum $\left(210 \mathrm{t} \mathrm{ha}^{-1}\right)$ was resulted from treatments combination of V4D3 that is variety of Suri 4 and mychorriza $15 \mathrm{~g}$ per plant. This suggests that these varieties are more responsive to mycorrhizal inoculation and respond to mycorrhizal level of treatments. Plant response to mycorrhizal application was affected mainly depends from varieties. Varieties Suri 3 (V1), Super 2 (V3), and Suri 4 (V4) elucidated more responsive result to mychorrizal plus in $15 \mathrm{~g}$ per plant of dose. According to [17] it was stated that plant root infections by mychorriza are determined by the compatibility between the plant and mychorriza. The presence of mychorriza has more advantage in the absorption of water and nutrients especially in 
phosphorus content, therefore resulted to increase the growth and production of plant especially in bagasse weight. The research result of [10] elucidated that $1 \mathrm{~kg}$ of bagasse produces (1.29 to 2.13) $\mathrm{mL}$ of ethanol depending on sorghum varieties. Variation result of ethanol content indicate a difference in cellulose and lignin content. It was stated [18] that stem baggage of sweet sorghum contains $45 \%$ cellulose, $27 \%$ hemicellulose, and $21 \%$ lignin which can be converted to $5804 \mathrm{~kg}$ of ethanol per ha. The differences in cellulose, lignin and other ingredients content in sorghum, provide a probability to affect the effectiveness of fermentation that affects ethanol production. Another attempt to use sweet sorghum stem bagasse as bioethanol feedstock can be done by enzymatic or acid hydrolysis method [19]. Therefore it can be said that bagasse is one of the criteria for selection of selection of sorghum varieties that potentially produce ethanol. The yield of ethanol was higher than that of the stem sap between (8.6 to 14.2 ) \% and the ethanol estimate of the fermented bagasse between (4.056 to 9.166) $\mathrm{L} \mathrm{ha}^{-1}[10]$.

Application of mycorrhizal dose plus only has no significant different to all variables. This means that the dose of mycorrhizal plus given has the same effect on the observed plant variables. This is because the dose interval between treatments is only a slight difference so that the effect is no different. The sorghum varieties independently had significant effect on stem height (Table 2), stem Dry Weight (DW), leaf DW, panicle DW and total biomass (Table 3) but not significantly on stem diameter and volume of sap (Table 4).

Table 2. Sorghum variety mean of stem height and stem diameter.

\begin{tabular}{|c|c|c|}
\hline Varieties & $\begin{array}{c}\text { Stem height } \\
(\mathrm{cm})\end{array}$ & Stem diameter $(\mathrm{cm})$ \\
\hline V1 & $268.03 \mathrm{~b}$ & 1.27 \\
\hline V2 & $192.38 \mathrm{a}$ & 1.44 \\
\hline V3 & $301.28 \mathrm{~b}$ & 1.39 \\
\hline V4 & $181.29 \mathrm{a}$ & 1.40 \\
\hline & & $\mathrm{ns}$ \\
\hline
\end{tabular}

Note: $n s=$ not significantly different; mean followed by the same letter are not significantly different based on the Duncan test at 0.5 level.

Table 3. Variety means of stem DW, leaf DW, panicle DW and total of biomass DW.

\begin{tabular}{|c|c|c|c|c|}
\hline Varieties & Stem DW $\left(\mathrm{tha}^{-1}\right)$ & Leaf DW $\left(\mathrm{t} \mathrm{ha}^{-1}\right)$ & Panicle DW $\left(\mathrm{t} \mathrm{ha}^{-1}\right)$ & Total of biomass DW $\left(\mathrm{t} \mathrm{ha}^{-1}\right)$ \\
\hline V1 & $18.07 \mathrm{bc}$ & $3.29 \mathrm{a}$ & $9.54 \mathrm{bc}$ & $30.90 \mathrm{~b}$ \\
\hline V2 & $15.26 \mathrm{~b}$ & $4.35 \mathrm{~b}$ & $8.04 \mathrm{ab}$ & $28.11 \mathrm{~b}$ \\
\hline V3 & $23.48 \mathrm{c}$ & $4.65 \mathrm{~b}$ & $11.35 \mathrm{c}$ & $39.98 \mathrm{c}$ \\
\hline V4 & $9.27 \mathrm{a}$ & $2.89 \mathrm{a}$ & $7.12 \mathrm{a}$ & $19.57 \mathrm{a}$ \\
\hline
\end{tabular}

Note: mean followed by the same letter are not significantly different based on the Duncan test at 0.5 level.

Table 4. Variety means of sugar content and juice production.

\begin{tabular}{|c|c|c|}
\hline Varieties & Sugar content (brix, \%) & Juice production $\left(\mathrm{L} \mathrm{ha}^{-1}\right)$ \\
\hline Suri 3 & $16.93 \mathrm{~b}$ & 2165.08 \\
\hline Kawali & $14.38 \mathrm{~b}$ & 1917.47 \\
\hline Super 2 & $14.44 \mathrm{~b}$ & 1415.88 \\
\hline Suri 4 & $10.39 \mathrm{a}$ & 2742.86 \\
\hline & & $\mathrm{ns}$ \\
\hline
\end{tabular}

Note: mean followed by the same letter are not significantly different based on the Duncan test at 0.5 level.

Variety of Super 2 (V3) has the highest stem that is $301.28 \mathrm{~cm}$ (Table 2) and followed by a high number of total biomass (Table 3), as stated at [20] that plant height is directly proportional to biomass. From 4 different varieties, variety of Super 2 (V3) has the highest result of the dry weight of stem, dry weight of leaf, dry weight of panicle and total of biomass. Biomass potential as an ethanol feedstock varies according to the content of cellulose and hemicellulose that can be converted to simple sugars. But not so with the juice production, the lowest Super 2 varieties are $1415.88 \mathrm{~L} \mathrm{ha}^{-1}$ (Table 4). The results showed that the sugar content was not directly proportional to the amount of juice produced. This is because there are several factors that affect the production of sap, among others, stem height, stem diameter, harvest time, varieties and sugar content in the sorghum stem. 
According to [21] that the sugar content in the stems of the sorghum plant varies for each variety, depending on the environmental conditions, the position of the stem segment, and the stages of the harvest time. The sugar content of the four varieties varied between (10.39 to 16.93$) \%$, the highest on the Suri 3 (V1) varieties (Table 4). The difference between sugar content and its composition in some sweet sorghum varieties will affect the variation of ethanol yield $[22,23]$.

\section{Conclusion}

In this experiment, the variety of sorghum tends to differ at 0.5 level from statistical analysis of variance and means comparison. Variety Super 2 (V3) has high total of biomass, this resulted variety Super 2 is potential as a raw material for bioethanol production. Variety of Suri 3 (V1) has the highest sugar content, meanwhile, variety of Suri 4 has the highest juice production.

\section{References}

[1] A. Almodares, R. Taheri, S. Adeli. J. Malesian Appl. Bio, 37:31-36(2008).

http://www.mabjournal.com/index.php?option=com content\&view=article\&id=335\&catid=59: currentview\&Itemid $=56$

[2] H. Fazaeli, H.A. Golmohhammadi, A. Almodares, S. Mosharraf, A. Shaei. Pakistan J. Biol. Sci., 9:2450-2455(2006). http://docsdrive.com/pdfs/ansinet/pjbs/2006/2450-2455.pdf

[3] A. Almodares, R. Taheri, Chung, M. Fathi. J. Environ. Biol, 29:849-852(2008). https://pdfs.semanticscholar.org/4cf9/2f2fff743f33372f6e894d3b856cae4830b3.pdf

[4] B.V.S. Reddy, S. Ramesh, P.S. Reddy, B. Ramaiah, P.M. Salimath, R. Kachapur. Int. Sorghum Millets Newslett, 46:79-86(2005). http://oar.icrisat.org/1234/1/ISMN-46 79-86 2005.pdf

[5] J. Yu, X. Zhang, T. Tan. Biomass and Bioenergy 33,3:521-526(2009). https://www.researchgate.net/publication/248353675_Optimization_of_media_conditions_for_the product ion of ethanol from sweet sorghum juice by immobilized Saccharomyces cerevisiae

[6] C.S. Wortmann, T. Regassa. Sweet sorghum as a bioenergy crop for the US great plains. Lincoln, USA: Department of Agronomy and Horticulture, University of Nebraska-Lincoln (2011). pp. 16.

https://www.intechopen.com/books/economic-effects-of-biofuel-production/sweet-sorghum-as-abioenergy-crop-for-the-us-great-plains/

[7] G.C. Rains, J.S. Cundiff, D.H. Vaughan. Trans. ASAE 33,1:56-62(1990). https://www.researchgate.net/profile/Glen_Rains/publication/259971357_Development_of_a WholeStalk Sweet Sorghum Harvester/links/5655cbeb08aeafc2aabdda63/Development-of-a-Whole-StalkSweet-Sorghum-Harvester.pdf

[8] FAO. Sweet sorghum in China. Department Agriculture and consumer protection, Food agricultural organization of United Nations (2002). http://www.fao.org/ag/portal/index_en.html

[9] H.B. Dinesh, M.R.G. Rao, A.M. Rao, S.J.S. Naik, H.N. Chetan, C.S. Shantharaja. Research Journal of Agricultural Sciences, 4,2:184-187(2013).

https://www.researchgate.net/profile/Shantharaja_Shivanna/publication/281446275_Evaluation_of_Sweet Sorghum_Sorghum bicolor_L_Moench_Cultivars_for_Ethanol_Yield_as_an_Alternate_Source_for_Bioenergy/links/55e7e4bb08ae3e1218421628/Evaluation-of-Sweet-Sorghum-Sorghum-bicolor-L-MoenchCultivars-for-Ethanol-Yield-as-an-Alternate-Source-for-Bio-energy.pdf

[10] M.B. Pabendon, S. Mas'ud, R.S. Sarungallo, A. Nur. Jurnal Penelitian Pertanian Tanaman Pangan, 31,1:60-69(2012). [In Bahasa Indonesia]. http://www.ejurnal.litbang.pertanian.go.id/index.php/jpptp/article/view/2880

[11] P. Tamang. Nitrogen fertilizer requirements for ethanol production from sweet and photoperiod sensitive sorghums in the Texas southern high plains. [Thesis]. Master of Science Texas Tech University (2010). https://www.researchgate.net/profile/Parikshya_Lama_Tamang2/publication/284690437_Nitrogen_fertiliz er_requirements_for_ethanol_production_from_sweet_and_fodder_quality_of_forage_sorghum_Sorghum bicolor_L_Moench/links/5691ef4408ae0f920dcb92cb/Nitrogen-fertilizer-requirements-for-ethanolproduction-from-sweet-and-fodder-quality-of-forage-sorghum-Sorghum-bicolor-L-Moench.pdf

[12] K.J. Han, W.D. Pitman, M. Kim, D.F. Day, M.W. Alison, M.M. Cormick, et al. GCB Bioenergy, 1-9(2012). http://www.lsuagcenter.com/MCMS/RelatedFiles/\%7BBE72439E-FBE9-4011-B6F1C3D1A5BD03DA\%7D/Ethanol-production.pdf 
[13] A. Almodares, M.R. Hadi. African J. Agri. 4,9:772-780(2009). http://www.academicjournals.org/journal/AJAR/article-full-text-pdf/6DDEDD738826

[14] M.B. Pabendon, M. Aqil, S. Mas'ud. Iptek Tanaman Pangan, 7,2:123-129(2012). [In Bahasa Indonesia]. http://pangan.litbang.pertanian.go.id/files/07-Marcia.pdf

[15] J.S. McLaren, N, Lakey, J. Osborne. Sorghum as a bioresources platform for future renewable resources. Proceeding 57th Corn and Sorghum Research Conference, CD ROM, 11-13 December 2002 (Illinois, Chicago, 2002). Alexandria, VA, USA: American Seed Trade Association (2003).

http://www.worldcat.org/title/proceedings-of-fifty-seventh-annual-corn-sorghum-seed-researchconference-and-proceedings-of-thirty-second-annual-soybean-seed-researchconference/oclc/54070386\&referer=brief_results

[16] K.S. Subramanian, P. Santhanakrishnan, P. Balasubramanian. Scientia Horticulturae 107:245-253(2006). https://www.sciencedirect.com/journal/scientia-horticulturae/vol/107/issue/3

[17] A. Tapwal, R. Kumar, D. Borah. Current Life Sciences, 2,1:1-8(2016). http://www.journals.tmkarpinski.com/index.php/cls/article/view/366/197

[18] M. Kim, D.F. Day. Journal of Industrial Microbiology and Biotechnology, 38,7:803-807(2011). https://www.ncbi.nlm.nih.gov/pubmed/20803247

[19] A.M. Kartini, E.S. Pandebesie. Jurnal Purifikasi, 16,2:118-129(2016). [In Bahasa Indonesia]. http://www.purifikasi.net/index.php/purifikasi/article/download/43/41/

[20] S. Mathur, A.V. Umakhant, V.A. Tonapi, R. Sharma, M.K. Sharma. Biotechnol Biofuels, 10,146:1-19(2017). https://biotechnologyforbiofuels.biomedcentral.com/articles/10.1186/s13068-0170834-9

[21] H.A. Qazi, S. Paranjpe, S. Bhargava. J Plant Physiol, 169,6:605-13(2012). https://www.ncbi.nlm.nih.gov/pubmed/22325624

[22] Y.L. Zhao, A. Dolat, Y. Steinberger, X. Wang, A. Osman, G. H. Xie. Crop Science, 111,1-2:55-64(2009). https://www.cabdirect.org/cabdirect/abstract/20093080407

[23] T.W. Pfeiffer, M.J. Bitzer, J.J. Toy, J.F. Pedersen. Crop Science, 50,5:1788-1794(2010). https://pdfs.semanticscholar.org/a235/b0bad3a4e08221bbf310769701f89658d169.pdf 